\title{
Impact of nitrogen fertilization on the forage characteristics and beef calf performance on native pasture overseeded with ryegrass
}

\author{
Daniel Martins Brambilla ${ }^{1}$, Carlos Nabinger ${ }^{1}$, Taise Robinson Kunrath ${ }^{1}$, Paulo César de \\ Faccio Carvalho ${ }^{1}$, Igor Justin Carassai ${ }^{1}$, Mónica Cadenazzi ${ }^{2}$
}

\author{
1 Universidade Federal do Rio Grande do Sul (UFRGS). \\ 2 Universidad de La República, EEMAC, Paysandú - Uruguay.
}

\begin{abstract}
The overseeding of ryegrass (Lolium multiflorum Lam) on sub-tropical native pastures increases the availability and quality of forage in the cold season. However, soil chemical amendment and nitrogen use can affect the floristic composition, with consequences to the primary and secondary production. In a randomized complete block design with three replications, the effect of nitrogen fertilization (40,90 and $140 \mathrm{~kg} / \mathrm{ha}$ of nitrogen) on native pasture overseeded with ryegrass in two consecutive years was assessed regarding production and composition of pasture and performance of beef calves. In both years, the forage accumulation rate and forage production responded linearly to the increase in nitrogen rates as a result of increased participation of ryegrass. The lower efficiency of responses in 2008 was due to the increased participation of dead material and the reduction of ryegrass in the forage sward. In 2007 there was an increasing substitution of the participation of native grasses by ryegrass with increasing nitrogen rates. Native legumes and other species were almost not affected by nitrogen fertilization. The average daily weight gain of the animals responded linearly to nitrogen rates in 2007, and quadratically in 2008. The stocking rate and gain per hectare increased linearly in both years, with greater responses in 2007. The production and composition of forage and livestock production are improved by the use of nitrogen, but the efficiency of responses can be affected by sowing date and nitrogen fertilization.
\end{abstract}

Key Words: average daily gain, forage accumulation rate, Lolium multiflorum, stocking rate

\section{Introduction}

In most native pastures of southern Brazil, there is predominance of the $\mathrm{C}_{4}$ species, which determines low pasture growth during the winter (Nabinger et al., 2009). The introduction of cultivated winter species by overseeding associated with fertilization, especially nitrogen, is an alternative to increase forage availability, reducing production seasonality (Ferreira et al., 2008).

The effects of nitrogen availability in the morphogenesis and on the efficiency of utilization of the other resources of the environment by the plants, such as solar radiation and water, are well known in mono specific pastures or even in simple mixtures (Lemaire \& Chapman, 1996). However, in more complex systems, such as natural grasslands, the increase in the availability of this element may alter the relations of plant competition, with results difficult to predict so far. Previous studies reported by Ferreira et al. (2008) and Nabinger et al. (2009), involving the response of natural pastures of Rio Grande do Sul to nitrogen, with or without the overseed of winter cultivated species, only quantified the effects of this nutrient in primary and/or secondary productivity, without assessing the ecophysiological mechanisms involved or its consequences to the floristic stability of the natural pasture.

The objective of this study was to quantify the effect of nitrogen fertilization on productive characteristics and floristic composition of the vegetation in natural pasture in the region of the Central Depression in Rio Grande do Sul overseeded with annual ryegrass and its possible effects on livestock production.

\section{Material and Methods}

The experiment was conducted at the Agricultural Experimental Station of Universidade Federal do Rio Grande do Sul (UFRGS), located at km 146 of BR - 290 in Eldorado do Sul (3005' $52^{\prime \prime}$ S, 51 ${ }^{\circ} 39^{\prime}$ '08" W and an average altitude of 46 meters), physiographic region of the Central Depression in RS. The soil in the experimental area is deep, well-drained sandy clay loam, classified as Red Dystrophic Argisol (EMBRAPA, 2006) (Table 1). Analysis was performed at the Soil Analysis Laboratory at UFRGS before and after the experimental period. Samples were taken at $10 \mathrm{~cm}$ depth, according to recommendation by CQFS (2004) for natural pastures without soil tilling. 
Table 1 - Soil characteristics of the experimental area $(0-10 \mathrm{~cm})$ before fertilization in 2007 and at the end of the experimental period in 2008. Average of $\mathrm{N}$ treatments

\begin{tabular}{|c|c|c|c|c|c|c|c|c|c|c|}
\hline & Clay (\%) & $\mathrm{pH}-\mathrm{H}_{2} \mathrm{O}$ & \multicolumn{2}{|c|}{ SMP index } & \multicolumn{2}{|c|}{$\mathrm{P}\left(\mathrm{mg} / \mathrm{dm}^{3}\right)$} & \multicolumn{2}{|c|}{$\mathrm{K}\left(\mathrm{mg} / \mathrm{dm}^{3}\right)$} & OM (\%) & $\mathrm{Al}\left(\mathrm{cmol}_{\mathrm{c}} / \mathrm{dm}^{3}\right)$ \\
\hline 007 & 17.2 & 5.5 & & 6.1 & \multicolumn{2}{|c|}{5.0} & \multicolumn{2}{|c|}{117.0} & 2.6 & 0.2 \\
\hline 2008 & 14.2 & 5.5 & & 6.1 & \multicolumn{2}{|c|}{20.3} & \multicolumn{2}{|c|}{137.9} & 2.9 & 0.3 \\
\hline 007 & $\begin{array}{c}\text { Ca }\left(\mathrm{cmol}_{\mathrm{c}} / \mathrm{dm}^{3}\right) \\
2.4\end{array}$ & $\operatorname{Mg}(\mathrm{cn}$ & & $\mathrm{H}+\mathrm{Al} \quad(\mathrm{c}$ & $\left./ \mathrm{dm}^{3}\right)$ & CTC & $\begin{array}{l}\left(\mathrm{cmol}_{\mathrm{c}} / \mathrm{dm}^{3}\right) \\
8.4\end{array}$ & Basis & $\begin{array}{l}\text { saturation (\%) } \\
\quad 48\end{array}$ & $\begin{array}{c}\text { Al saturation (\%) } \\
2.4\end{array}$ \\
\hline 008 & 2.9 & & & & & & 8.3 & & 54.4 & 5.8 \\
\hline
\end{tabular}

SMP Index - potential acidity of the soil; OM - organic matter.

The climate in the region is humid subtropical with hot summers, fundamental type "Cfa” according to the Köppen climatic classification (Moreno, 1961). Average annual rainfall is $1440 \mathrm{~mm}$, with most rainfall occurring between April and September, with normal monthly average of $120 \mathrm{~mm}$ (Bergamaschi et al., 2003). The meteorological data recorded during the experimental period were obtained from a meteorological station, located at about $300 \mathrm{~m}$ from the experimental site. During the study period, rainfall was higher than the normal, with excessive rain occurrence in the first two weeks of April in the year 2007 (Figure 1). Average temperature and solar radiation were below normal through most of the experimental period in both years.

The vegetation of the area where the experiment was conducted is characterized as secondary succession of natural pasture. In 1996, the soil was limed and fertilized by surface application without soil tilling, lime ( $3 \mathrm{t} / \mathrm{ha}$, corrected to $100 \%$ of relative neutralization power) and $500 \mathrm{~kg} / \mathrm{ha}$ of 5-20-20 fertilizer. Then a sequence of studies were carried out with cattle grazing as described by Carassai et al. (2008), where annual nitrogen rates (zero, 100 and $200 \mathrm{~kg} / \mathrm{ha}$ of N) were tested, but without reapplication of lime, P or K until 2004. In 2004, the same treatments were maintained, but with the use of grazing lambs (Carassai et al., 2008). On this occasion, another application of base fertilizer was carried out $(250 \mathrm{~kg} / \mathrm{ha}$ of the 5-20-20 formula). In the following two years (2005-06) the area remained under moderate grazing and no fertilization. In 2007 and 2008 (this study), the area was used with cattle again, but a replication was added to the experimental units, changing the total area of the experiment from 3.2 to 4.7 ha. The experimental units measured 0.65 ha in N40, 0.54 ha in N90 and 0.44 ha in N140. The replication area added was grazed by cattle, but never received soil correction or fertilization. Then, 3t/ha of lime were applied on coverage, in January 2007. In both years, the introduction of annual ryegrass (Lolium multiflorum Lam) cv. common was carried out in direct sowing after a period of high grazing pressure and mechanical mowing. Sowing was carried out with direct drilling equipment with 15 rows placed $20 \mathrm{~cm}$ apart with density of $40 \mathrm{~kg} / \mathrm{ha}$. In both years, $330 \mathrm{~kg} / \mathrm{ha}$ of ammonium phosphate fertilizer (12\% $\mathrm{N}$ and $52 \% \mathrm{P}_{2} \mathrm{O}_{5}$ ) were applied in the rows at sowing.
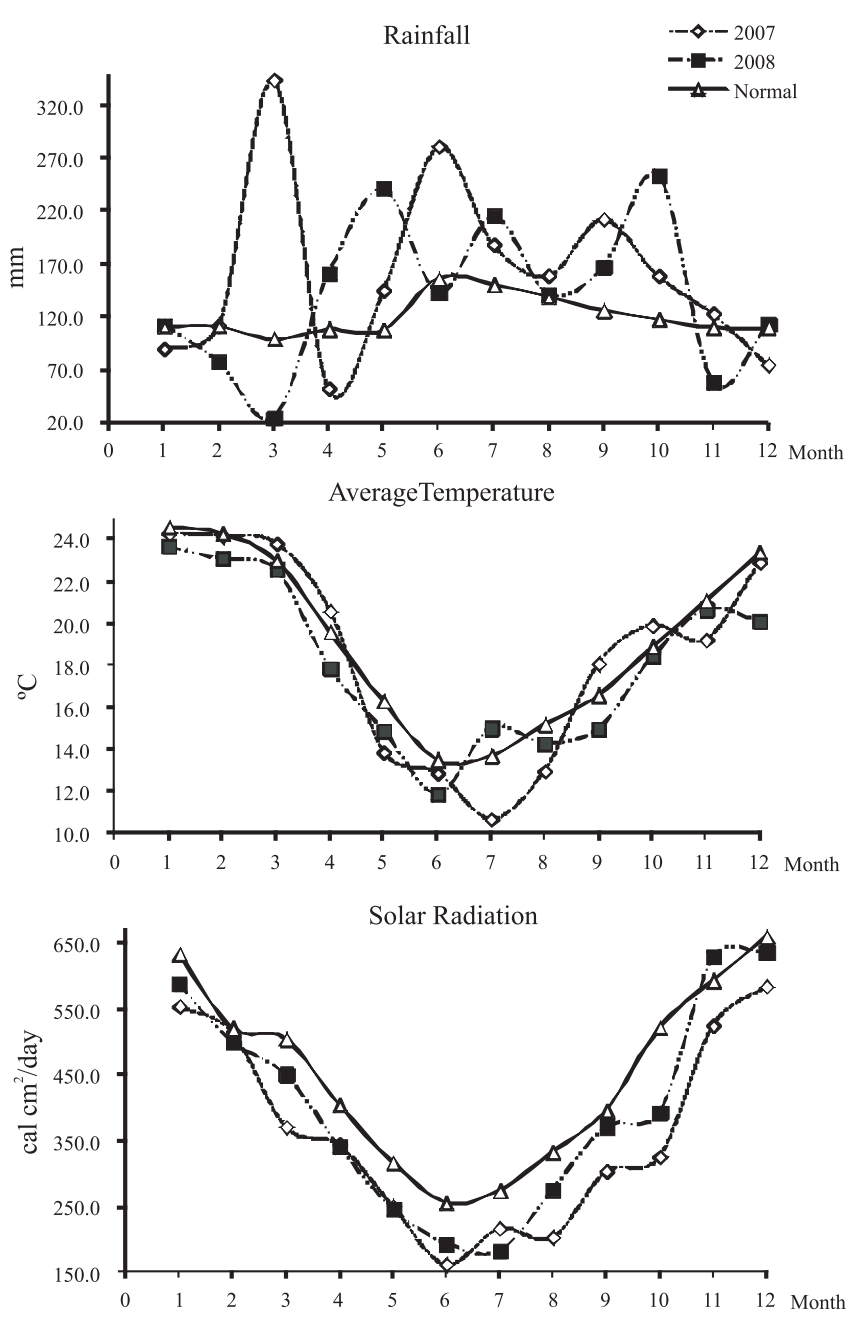

Figure 1 - Monthly normal and occurring rainfall, average temperature and solar radiation in 2007 and 2008 in Eldorado do Sul - RS. Normal values for solar radiation from 1969-1999 and for rainfall and temperature from 1970-2000.

The treatments consisted of the following $\mathrm{N}$ rates: 40 , 90 and $140 \mathrm{~kg} / \mathrm{ha} /$ year of $\mathrm{N}$, arranged in three completely randomized blocks. Forty kilograms of $\mathrm{N}$ were applied at the base fertilization at sowing and the remainder was broadcast as urea. Urea fertilization was splitted into two applications per year. The periods of forage and livestock assessment comprised 93 days in 2007 and 95 days in 2008 (Table 2). 
The grazing system was continuous with variable stocking rate in order to maintain an intended forage allowance of $12 \%$ (12 kg of dry matter (DM) per $100 \mathrm{~kg}$ of live weight). Crossbred heifers, mostly Braford, at an approximate age of eight months, and average initial weight of $113.6 \pm 7.2$ in 2007 and $101.5 \pm 15.7 \mathrm{~kg}$ in 2008 were used.

Stocking rate was periodically adjusted based on the sum of forage mass available at the beginning of each subperiod and the DM forage accumulation rate occurred in the immediately preceding sub-period. Thus, the stocking rate required to achieve the pre-established forage allowance was calculated using the formula $\mathrm{SR}=\{[(\mathrm{FMi}+\mathrm{AR} *$ days $) /$ days] $\times 100]\} / I A$, where SR is the stocking rate in $\mathrm{kg}$ of live weight, $\mathrm{FMi}$ is forage mass in $\mathrm{kg} \mathrm{DM} /$ ha estimated at the beginning of the sub-period, AR is the forage accumulation rate of the immediately preceding sub-period, days is the number of days in the sub-period and IA is the intended level or forage allowance. The animals were weighed every 28 days throughout the experimental period and fasted 12 hours before the initial and final weighing of the experiment. In intermediate weighing, fasting lasted 6 hours, based on Hart \& Hoveland (1989) and Stuedmann \& Matches (1989).

The actual forage allowance was recalculated based on the average of initial and final forage masses of each 28-day period; the dry matter accumulation rate occurred in the corresponding period. To estimate forage mass ( $\mathrm{kg} / \mathrm{ha}$ of DM), the double sampling technique described by Wilm et al. (1944) was used, with 30 visual samples per experimental unit in each assessment. Along with these samples, the representative height of plants in these points was measured with a sward stick according to Barthram \& Grant (1984). The average value of visual estimates of each paddock in each assessment was corrected by the equation obtained by the mathematical relationship between the visual scores assigned to the dry forage masses (DM) of 54 samples cut in and out of exclusion cages in areas of $0.5 \times 0.5 \mathrm{~m}$ which had their masses measured. The cut material was oven-dried $\left(60^{\circ} \mathrm{C}, 72\right.$ hours) for weighing and determination of dry matter. These values were used to establish the relationship between the visual and actual estimates by linear regression.

In the samples taken out of the exclusion cages (three per experimental unit), manual separation of the components ryegrass, native grasses, native legumes, other plant species and dead material was performed, and the results were expressed as percentages based on dry weight. In 2007, these components were determined at the beginning of all periods of stocking rate adjustment, while in 2008, due to problems of material deterioration during storage, only the initial and final periods were considered.

To assess the effects of treatments on vegetation, a floristic survey was carried out at the end of the second year (2008), using the Botanal method described by Tothil (1979) in six frames $(0.5 \times 0.5 \mathrm{~m})$ per experimental unit in representative vegetation areas.

To estimate the accumulation daily rate of dry matter ( $\mathrm{kg} / \mathrm{ha}$ ), the double sampling technique (Klingman et al., 1943) was used in three exclusion cages per experimental unit. The accumulation rate was obtained each 28 days by the difference in forage mass outside the cage in measuring $\mathrm{i}-1$ and the forage mass in the cage in measuring $\mathrm{i}$, according to Campbell (1966). The production of total forage mass ( $\mathrm{kg} \mathrm{DM} / \mathrm{ha}$ ) was calculated as the sum of the products of the accumulation rates and the number of days of each period. The total forage availability was calculated by adding the initial forage mass to the total forage mass production.

The adjustment of stocking rate ( $\mathrm{kg} / \mathrm{ha}$ of live weight) in each experimental unit to achieve the intended allowance was carried out immediately after the estimates of forage availability. The average daily weight gain (kg live weight/ animal/day) of the tester animals was obtained by the difference between weightings made at the beginning and end of each experimental sub-period, divided by the number of days the animals remained on the pasture. The live weight

Table 2 - Dates of activities in both experimental years

\begin{tabular}{|c|c|c|c|c|c|c|c|c|c|c|}
\hline \multirow[b]{2}{*}{ Activity } & \multicolumn{10}{|c|}{ Period } \\
\hline & Year & Mar. & Apr. & May & June & July & Aug. & Sept. & Oct. & Nov. \\
\hline Mowing and grazing & 2007 & 12 to 15 & & & & & & & & \\
\hline \multirow[t]{2}{*}{ Ryegrass sowing and fertilization } & 2007 & & $4 / 20$ & & & & & & & \\
\hline & 2008 & & & & $6 / 19$ & & & & & \\
\hline Urea application & 2007 & & & $5 / 30$ & & $7 / 14$ & & & & \\
\hline Grazing period & 2008 & & & & & & $8 / 7$ & & & $11 / 10$ \\
\hline \multirow[t]{2}{*}{ Pasture and livestock assessment } & 2007 & & & & & $7 / 16$ & $8 / 13$ & $9 / 12$ & $10 / 17$ & \\
\hline & 2008 & & & & & & $8 / 7$ & $9 / 8$ & $10 / 6$ & $11 / 10$ \\
\hline
\end{tabular}


gain per area (kg live weight/ha) was calculated by multiplying the average daily gain by the number of animals/day/ha. The average stocking rate of each subperiod is the arithmetic mean of the stocking rate at the beginning and end of the sub-periods. The average stocking rate divided by the weight of the tester animals results in the variable animals/day/ha.

For the initial forage mass results, variance analysis and $\mathrm{F}$ test at significance level of $10 \%$ were performed, and the averages were compared by Tukey test at $10 \%$. This level of significance was adopted due to high coefficients of variation usually observed in grazing experiments on natural pastures. The remaining variables were submitted to regression analysis. Analyses were performed using computer software SAS (Statistical Analysis System, version 6.12) for each year separately, considering the differences of the procedures adopted in each year, such as sowing dates, time of nitrogen application and the grazing periods considered .

To describe botanical composition as affected by nitrogen levels, main components analysis was done using values of coverage percentage of the species surveyed in each experimental unit and also the average values per treatment. The square Euclidean distance was calculated with the values of each experimental unit and then synthesized in average values by treatment (Di Rienzo et al., 2010).

\section{Results and Discussion}

Actual forage allowances did not differ in the treatments in both years, but were lower than the intended in 2007 (IA $=9.9 \mathrm{~kg}$ of DM/100 kg of live weight) and slightly higher in 2008 (12.8 kg of DM/100 kg of live weight). The larger difference between the intended and the actual allowance in the first year was due to overestimation of forage accumulation rate because average temperatures were lower than the normal. However, these levels of forage allowance were very close to the optimal range determined by Maraschin et al. (1997), which is between 11 and 13\%. This may slightly affect individual gain, although it comes close to maximum gain per area. No difference in allowance in the treatments is desirable because it avoids possible bias due to different grazing pressures when the forage allowance is not similar between treatments.

The forage masses available at the time of the entry of the animals (Figure 2) were significantly affected by the treatments in both years $(\mathrm{P}=0.0291$ and $\mathrm{P}=0.0963$ for 2007 and 2008, respectively). In both years there was no significant difference between forage masses of treatments N90 and N140, which were higher than the one in N40. In 2008, the values of dry forage mass were higher than those in the previous year due to higher residual mass of native pasture at the ryegrass sowing, which happened because of the longer interval between grazing and mowing and the ryegrass sowing. A larger amount of rainfall in the same period also contributed.

The initial forage mass composition (Table 3) clearly demonstrates the different responses in pasture composition by the use of similar nitrogen rates when management conditions are different, as occurred in both years.

In 2007, there was equilibrium between ryegrass and native grasses contributions, with no significant effect of nitrogen levels $(\mathrm{P}=0.0847)$. In 2008 , ryegrass contribution at the lowest nitrogen rate was lower $(P=0.002)$ and accounted for only $4.0 \%$ of the total forage mass, while native grasses accounted for $39 \%$ of the above ground

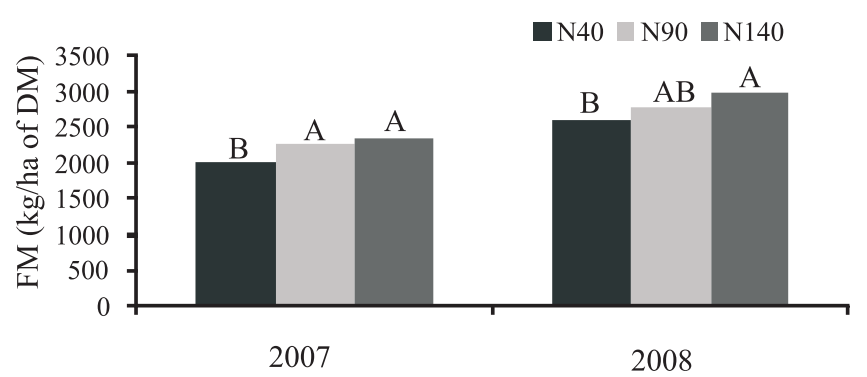

Figure 2 - Initial forage mass (FM) in natural pasture of the Central Depression in Rio Grande do Sul, overseeded with annual ryegrass and subjected to nitrogen levels $(\mathrm{N} 40=40 \mathrm{~kg} / \mathrm{ha}$ of $\mathrm{N} ; \mathrm{N} 90=90 \mathrm{~kg} / \mathrm{ha}$ of N; N140 = $\mathrm{kg} / \mathrm{ha}$ of N) in 2007 and 2008.

Table 3 - Aerial biomass composition of natural pasture overseeded with ryegrass and fertilized with different nitrogen doses at the entry of animals in each experimental year (July 16, 2007 and August 7, 2008)

\begin{tabular}{|c|c|c|c|c|c|c|}
\hline \multirow[t]{3}{*}{ Botanical component } & \multicolumn{3}{|c|}{ Year I - 2007} & \multicolumn{3}{|c|}{ Year II - 2008} \\
\hline & \multicolumn{6}{|c|}{ Nitrogen levels } \\
\hline & 40 & 90 & 140 & 40 & 90 & 140 \\
\hline Ryegrass & $25.1 \%$ & $33.0 \%$ & $29.8 \%$ & $4.0 \%$ & $37.5 \%$ & $34.3 \%$ \\
\hline Native grasses & $28.0 \%$ & $31.4 \%$ & $30.4 \%$ & $39.0 \%$ & $27.4 \%$ & $25.0 \%$ \\
\hline Native legumes & $0.1 \%$ & $0.0 \%$ & $0.1 \%$ & $0.3 \%$ & $0.1 \%$ & $0.0 \%$ \\
\hline Other species & $15.4 \%$ & $14.0 \%$ & $14.0 \%$ & $8.9 \% a b$ & $21.7 \%$ a & $2.8 \% \mathrm{~b}$ \\
\hline Dead material & $31.4 \%$ & $23.0 \%$ & $28.5 \%$ & $53.7 \% a$ & $23.2 \% \mathrm{c}$ & $37.9 \% \mathrm{~b}$ \\
\hline
\end{tabular}


pasture biomass. Ryegrass contribution in this year did not differ between N90 and N140, averaging 36\%, slightly higher than the $31 \%$ of the previous year. At the entry of the animals, in both years, only $50 \%$ of the total nitrogen of the treatments had been applied, which probably determined the lack of response to the higher dose (N140). The dead material contribution at the beginning of grazing was significantly higher in low nitrogen treatment in 2008 $(\mathrm{P}=$ 0.0198). This was due to the long period between grazing and mowing and sowing, as well as the late entry of the animals in the experiment (August 7, 2008). In this same year, the contribution of species considered undesirable to grazing (other species) was also significantly higher in the treatment fertilized with the intermediate nitrogen level $(\mathrm{P}=0.098)$.

Analyzing the average contribution in terms of forage mass of the botanical components of the pasture during the experimental periods (Figure 3), it is clear that there was no significant effect of nitrogen rates in the legumes contribution in any year, because this component always contributed with less than $1 \%$ of the total forage mass. The other species, considered undesirable species, represented in the first year an average of $14.5 \%$ of the total forage mass, while in the second year there was a significant effect on the percentage of this component, described by a quadratic model.

In both years, there was a significant and positive effect of ryegrass contribution in the total forage mass in response to N (Figure 3). Native grasses contribution also followed a quadratic response model and inverse to the ryegrass model, but only in 2007. In 2008, the percentage contribution response of this component in the total dry matter was not significant.

The different responses to nitrogen observed in the two-year experiment can be attributed mainly to ryegrass overseeding date (April 20, 2007 and June 19, 2008) and to the pasture management prior to ryegrass sowing. In 2007, sowing was carried out soon after high grazing pressure and mowing, while in 2008, sowing was carried out after about a month, due to excessive rainfall. The rainfall occurrence higher than normal (Figure 1) determined the recovery of natural pasture, whose plants exercised higher competition in the treatment where the ryegrass received only $40 \mathrm{~kg} / \mathrm{ha}$ of $\mathrm{N}$. In the other nitrogen fertilizations, the application of $\mathrm{N}$ was sufficient to allow ryegrass to compete with native species, resulting in similar responses (30\% of ryegrass contribution in the pasture composition) in both years. The lower response in the second year comparing with the first with respect to the maximum values reached is equally explained by
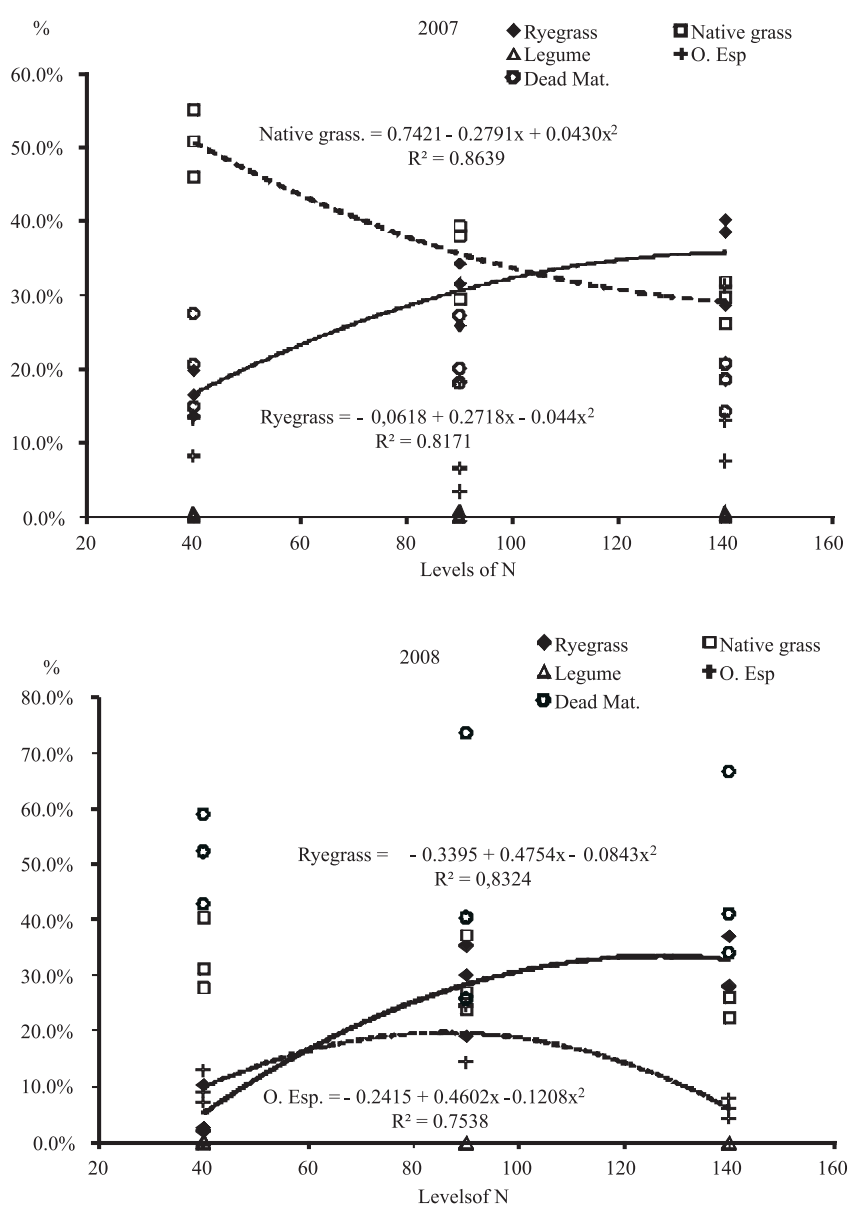

Figure 3 - Response of the average percentage contribution on biomass of the main components of the natural pasture overseeded with ryegrass to nitrogen levels in 2007 and 2008.

the delay in sowing, but also by the late application of the remaining rate of nitrogen ( $50 \%$ in October), which limited the period of response, because in September, ryegrass will usually be induced to flower.

A more significant contribution of native species in the period between ryegrass sowing and the entry of animals in August 2008 caused greater contribution of dead material in this year when compared with the previous year. This participation was greater with the lower the rate of nitrogen applied, which can be partly explained by the shorter leaf life span with lower availability of this element (Lemaire \& Chapman, 1996). The lower tolerance to cold in low nitrogen availability (Taiz \& Zeiger, 2006) of predominantly summer native species in native pastures of this region (Boldrini, 1997) must also have contributed to the increased contribution of dead material.

The average residual forage mass of was only dependent on treatments in the first year, while the accumulation forage rate and the total dry matter production responded linearly to nitrogen in both years (Tables 4 and 5). The 
differences in residual mass in the first year are due to possible errors in the estimates of projected accumulation rates, leading to an overestimation of the stocking rate, which can be evidenced by the lower forage allowances obtained that year. However, the differences observed in the residue did not affect the results, since the forage masses maintained (1461 to $1796 \mathrm{~kg} / \mathrm{ha}$ of DM in 2007 and above $2000 \mathrm{~kg} \mathrm{DM} / \mathrm{ha}$ in 2008) are close to or above the minimum that limits intake in this kind of pasture (Gonçalves et al., 2009), not compromising the comparison of treatments.

Nitrogen availability is essential for growth and development of plant tissues, increasing appearance and elongation leaf rates (Lemaire \& Chapman, 1996). The linear responses observed indicate, however, that the rates used were not sufficient to achieve maximum pasture growth. The models indicate an increase of $0.210 \mathrm{~kg} / \mathrm{ha} /$ day of DM in the forage accumulation rate for each additional kilogram of nitrogen applied in 2007 and $0.153 \mathrm{~kg} / \mathrm{ha} /$ day of DM in 2008 in accordance with Freitas (2003).

The total production of forage mass during the experimental periods also showed linear responses to the amount of nitrogen applied (Figure 4) since they are dependent on accumulation rates. Forage production increased 19 and $15 \mathrm{~kg} / \mathrm{ha}$ of DM per $\mathrm{kg}$ of additional $\mathrm{N}$ in the first and second years, respectively. While working on singular pastures of annual ryegrass, Freitas (2003) found responses of about $19 \mathrm{~kg} / \mathrm{ha}$ DM per kg of additional N.

The total DM production (Figure 4) ranged from 2,021 to 3,950 kg of DM/ha and 2,775 to 4,266 kg DM/ha for 2007 and 2008, respectively; these values are lower than those found by Rizo et al. (2004) and Ferreira et al. (2011). Nevertheless, the values reported by these authors, which reached productions of 5016 and $5943 \mathrm{~kg} / \mathrm{ha}$ of DM, refer to a period substantially longer than 300 days, both in native pasture fertilized and overseeded with winter species, while in this study accumulated DM production was calculated over 93 and 95 days of grazing in 2007 and 2008. Total production of N140 was 3,950 and 4,266 kg/ha, about twice the N40 in those years (2,021 and 2,775 kg/ha, respectively). This variable was highly correlated with AR $(\mathrm{P}<0.0001$; $\mathrm{r}=0.9997$, in 2007; $\mathrm{P}<0.0001 ; \mathrm{r}=0.9995$ in 2008) and with nitrogen treatments $(\mathrm{P}=0.0034 ; \mathrm{r}=0.8538$ in $2007 ; \mathrm{P}=0.0500$; $r=0.6664$ in 2008).

The lowest amount of $\mathrm{N}$ applied in treatment $\mathrm{N} 40$ also reflected in lower forage production due to lower ryegrass contribution in the available forage mass (Figure 3). This species is more demanding of nutrients, especially $\mathrm{N}$, and this effect was expected when the mineral $\mathrm{N}$ addition to the system was low, unlike what occurred in other treatments (N90 and N140).

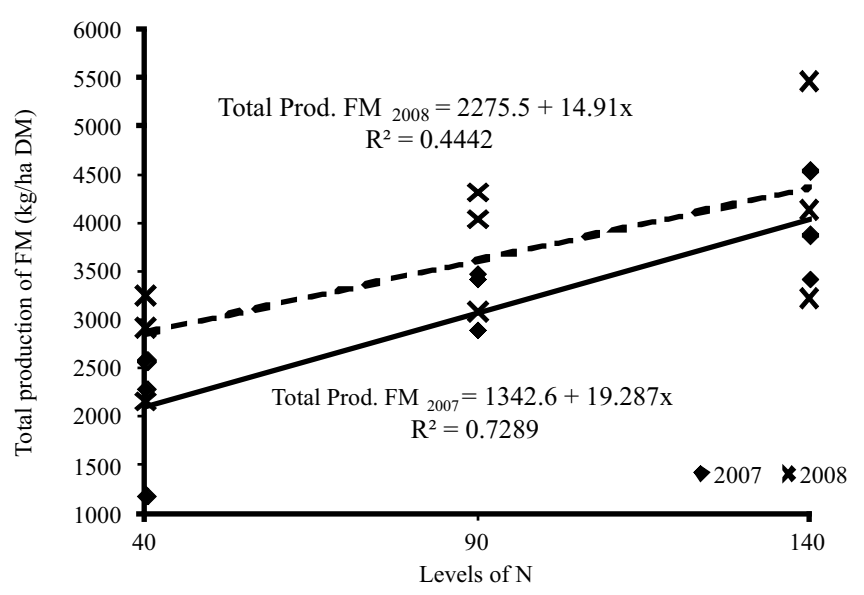

Figure 4 - Total production of forage mass (FM) accumulated in native pasture improved with nitrogen fertilization and overseeded with ryegrass in 2007 and 2008. (2007: $\mathrm{P}=0.0034$ and $2008 \mathrm{P}=0.0500$ ).

Table 4 - Models of response of total forage mass (FM), sward height (HE), daily accumulation rate (AR) and total forage availability (Avail.) in native pasture overseeded with ryegrass and fertilized with nitrogen levels in 2007

\begin{tabular}{|c|c|c|c|c|}
\hline Variable & Probability & $\mathrm{R}^{2}$ & Model & Regression \\
\hline FM & 0.0011 & 0.8965 & Quadratic & $y=942.41+15.75 x-0.07 x^{2}$ \\
\hline $\mathrm{HE}$ & 0.0002 & 0.9450 & Quadratic & $\mathrm{y}=1.28+0.19 \mathrm{x}-0.0009 \mathrm{x}^{2}$ \\
\hline AR & 0.0034 & 0.7301 & Linear & $y=14.62+0.21 x$ \\
\hline
\end{tabular}

Table 5 - Models of response of total forage mass (FM), daily accumulation rate (AR), height (HE), and total forage availability (Avail.) in native pasture overseeded with ryegrass and fertilized with nitrogen levels in 2008

\begin{tabular}{lcccc}
\hline Variable & Probability & $\mathrm{R}^{2}$ & Model & Regression \\
\hline FM & 0.5561 & - & NS & - \\
AR & 0.0515 & 0.4397 & Linear & $\mathrm{Y}=24.20+0.15 \mathrm{x}$ \\
HE & 0.0208 & 0.5573 & Linear & $\mathrm{Y}=7.86+0.03 \mathrm{x}$ \\
Avail. & 0.0226 & 0.5476 & Linear & $\mathrm{Y}=4695.91+18.75 \mathrm{x}$ \\
\hline
\end{tabular}


The botanical survey demonstrated the existence of 39 species of 32 genera and 15 families. Poaceae was the most important family, contributing with 21 species, followed by Asteraceae, with three species. It is observed that $100 \%$ of the total variability is explained by the first two main components (Figure 5). The contribution of each species is similar, especially the species that appear with more than $20 \%$ in any of the two axes.

The highest nitrogen fertilization rates (N90 and N140) allow for the preservation of native pasture species. In addition to obtaining the greatest number of species (26), there are species with better forage value as Coelorachis selloana, Stipa sp. Paspalum notatum and P. urvillei. Besides the native species, ryegrass also has a high correlation with the highest $\mathrm{N}$ rates (Table 6).

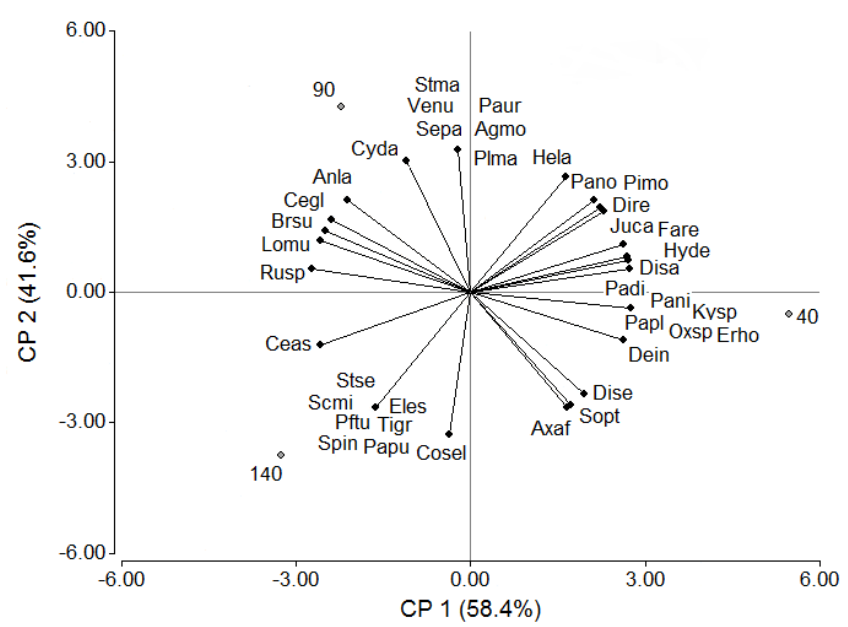

Figure 5 - Diagram of ordination by principal coordinates, based on floristic composition data of 2008 and on $\mathrm{N}$ rates. (Agmo - Agrostis montevidensis; Anla-Andropogon lateralis; Axaf - Axonopus affinis; Brsu - Brisa subaristata; Ceas - Centela asiática; Cegl - Cerastium glomeratum; Cosel - Coelorachis selloana; Cyda Cynodon dactylon; Dein - Desmodium incanum; Disa - Dicantelium sabulorum; Dire - Dichondra repens; Dise - Dichondra sericia; Eles - Eleusine sp.; Erho Eryngium horridum; Fare - Facelis retusa; Hela Herbertia lahue; Hyde - Hypoxis decumbens; Juca Juncus capilacius; Kysp - Kylinga sp; Lomu - Lolium multiflorum; Oxsp - Oxalis sp; Padi - Paspalum dilatatum; Pani - P. nicorae; Pano - P. notatum; Papl -P. plicatulum; Papu-P. pumilum; Paur-P. urvillei; Pftu - Pfafia tuberosa; Pimo - Piptochaetium montevidensis; Plma - Plantago major; Rusp - Rumex sp; Scmi - Schyzachirium microstachium; Sepa Setaria parviflora; Sopt - Soliva pterosperma Juss. Less.; Spin - Sporobulus indicus; Stma - Stipa macrocefala; Stse - Stipa setigera; Tigr - Tibouchina gracilis; Venu - Vernonia nudiflora).
Table 6 - Species most associated to the different nitrogen treatments

N40 Centella asiatica, Desmodium incanum, Dichanthelium sabulorum, Eryngium horridum, Facelis retusa, Hypoxis decumbens, Juncus capillaceus, Kyllinga sp., Oxalis sp., $P$. dilatatum, P. nicoreae, $P$. plicatulum

N90 Agrostis montevidensis, Herbertia lahue, Lolium multiflorum, Paspalum urvillei, Plantago major, Rumex sp., Setaria parviflora, Stipa macrocefala, Vernonia nudiflora

N140 Axonopus affinis, Coelorachis selloana, Eleusine sp., L. multiflorum, P. notatum, Pfaffia tuberosa, Rumex sp., Schizachyrium microstachyum, Soliva pterosperma, Sporobulus indicus, Stipa setigera, Tibouchina gracilis

The contribution of Desmodium incanum only to the treatment with lower $\mathrm{N}$ dose indicates that probably the higher levels determines a decrease in the activity of associated rhizobium (Wery, 1987). Besides this species, Eryngium horridum, was also only present in this treatment. This result agrees with those obtained by Fontaneli et al. (1995), Silva \& Jacques (1993) and Castilhos \& Jacques (2000), who observed a decrease in contribution of Eryngium sp. with the introduction of other plant species, correction of soil $\mathrm{pH}$ and fertilization on natural pasture. Another factor that contributes to the decreasing contribution of these two species with increasing nitrogen levels is a greater competition from grasses, more benefited by nitrogen. Nitrogen availability affects root formation, photosynthesis and, therefore, plant growth rate (Taiz \& Zieger, 2006). However, the increased availability of N, also caused the increased contribution of undesirable species, such as Rumex sp. and Soliva pterosperma. These are opportunistic species, with better resource absorption and use capacity (Lorenzi, 2008) and which benefit from the application of fertilizers.

The individual performance of the animals was affected significantly by nitrogen levels in both years (2007, $\mathrm{P}=0.0503 ; 2008, \mathrm{P}=0.0854$ ), however, the response model was different in each year (Figure 6). This effect in performance is explained by the increased contribution of ryegrass and the greater amount of forage available in the treatments with higher nitrogen fertilization (Figures 3 and 4).

In 2007, individual gains responded linearly to increasing $\mathrm{N}$ levels, while in 2008, the response was quadratic. This was due to the different experimental period, which lasted until November in this year, determining lower quality ryegrass allowance because the plants were approaching the reproductive and final stage of the cycle.

In the Campanha region of Rio Grande do Sul, Fontoura Júnior et al. (2000) quantified daily gains of $0.640 \mathrm{~kg} / \mathrm{animal}$ on native pasture overseeded with oat and ryegrass, which 


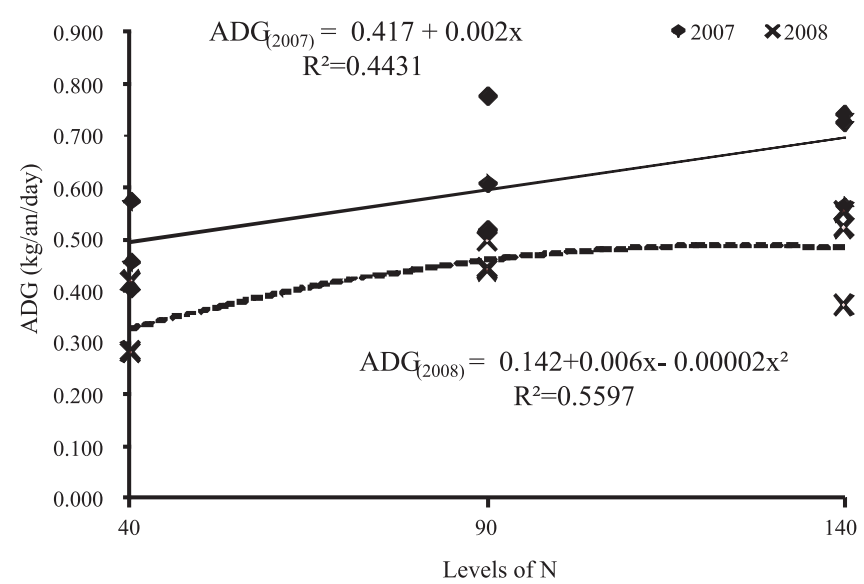

Figure 6 - Average daily gain (ADG) of beef calves on native pasture overseeded with ryegrass and fertilized with nitrogen levels in 2007 and 2008.

is similar to the results described in this study. Correa \& Silva (1998) observed daily gains higher to the ones referred to in this study, with 1.10 and $1.07 \mathrm{~kg} /$ animal on native pasture overseeded with ryegrass, white clover and Lotus corniculatus. The difference observed in the latter is due to the presence of legumes, which provided higher quality to forage intake.

For both the stocking rate (SR) and the gain per area (GA) (Figure 7) significant linear regressions were verified in both years (2007: $\mathrm{P}=0.0027$, $\mathrm{SR}$ and $\mathrm{P}=0.0013$, GA; 2008: $\mathrm{P}=0.0004$, SR and $\mathrm{P}=0.0011, \mathrm{GA})$. This response was expected because the higher the nitrogen level applied, at least to some degree, the higher the dry matter production, hence the increasing pasture availability and its carrying capacity. The stocking rate is positively correlated with the total availability of DM (Tables 4 and 5), with the coefficients in 2007, $\mathrm{r}=0.7476(\mathrm{P}=0.0206)$ and in $2008, \mathrm{r}=0.6838$ $(\mathrm{P}=0.0422)$.

In order to obtain satisfactory and appropriate animal gain to the goals of the system, stocking rate must be related to the forage mass available to animals (Fagundes et al., 2003). In low stoking rate, higher average daily gain is observed, due to increased food availability (Fagundes et al., 2003). In a similar study conducted in the Campanha region of RS by Fontoura Júnior et al. (2000), stocking rates of 501,300 and $361 \mathrm{~kg} / \mathrm{ha}$ of live weight were quantified for the following treatments: native pasture overseeded with ryegrass, white clover and Lotus corniculatus and fertilized with $89 \mathrm{~kg} / \mathrm{ha}$ of $\mathrm{P}_{2} \mathrm{O}_{5}$ and $17 \mathrm{~kg} / \mathrm{ha}$ of $\mathrm{N}$; overseeded native pasture and use of glyphosate; and overseeded native pasture and use of glyphosate and double fertilization (178 kg/ha of $\mathrm{P}_{2} \mathrm{O}_{5}$ and $34 \mathrm{~kg} / \mathrm{ha}$ of $\mathrm{N}$ ), respectively. In this research, it was possible to use larger
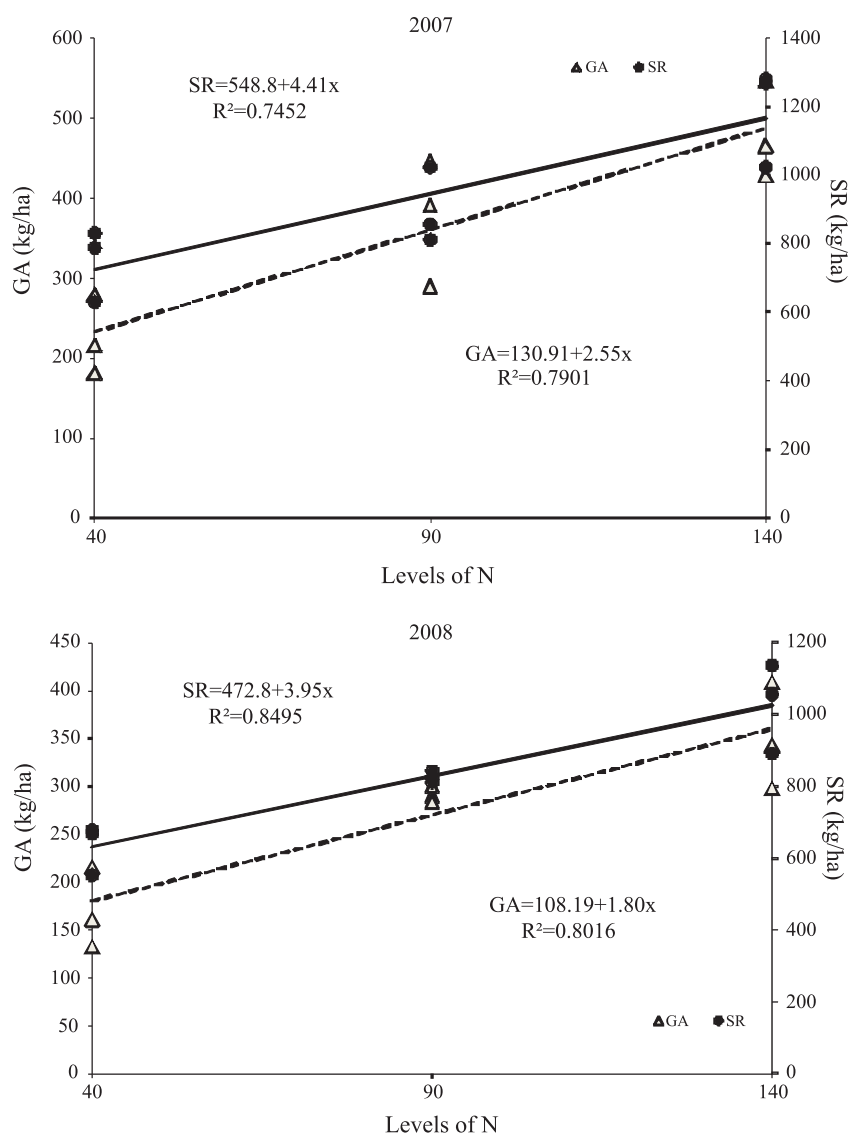

Figure 7 - Gain per area (GA) and stocking rate (SR) of calves on native pasture overseeded with ryegrass and fertilized with nitrogen levels in 2007 and 2008.

stocking rates than those referred by the authors mentioned above, probably because of the use of higher nitrogen levels. Rizo et al. (2004) obtained stocking rate similar to this study, 1,003 and 1,221 kg LW/ha, on native pasture overseed with ryegrass, white clover and Lotus corniculatus and fertilization, with or without glyphosate application, respectively.

\section{Conclusions}

Nitrogen fertilization in native pasture overseeded with ryegrass allows for greater stocking rate and gain per animal and per area compared with overseed native pasture with no $\mathrm{N}$ covering. The productivity of these pastures is highly dependent on the nitrogen rate applied, and fertilization up to $140 \mathrm{~kg} / \mathrm{ha}$ of $\mathrm{N}$ does not allow attaining pasture potential. The botanical composition of natural pastures overseeded with ryegrass is modified by the increase in nitrogen rates applied, with no harm to animal production in the short term and in the intervals tested. 


\section{References}

BARTHRAM, G.T.; GRANT, S.A. Defoliation of ryegrass dominated sward by sheep. Grass and Forage Science, v.39, n3, p.211219, 1984.

BERGAMASCHI, H.; GUADAGNIN, M.R.; CARDOSO, L.S. et al. Clima da Estação Experimental da UFRGS (e Região de Abrangência). Porto Alegre: UFRGS, 2003. 78p.

BOLDRINI, I.I. Campos do Rio Grande do Sul: caracterização fisionômica e problemática ocupacional. Porto Alegre: Universidade do Rio Grande do Sul, 1997. 39p. (Boletim do Instituto de Biociência, 56).

CAMPBELL, A.G. Grazed pastures parameters: I. Pasture dry matter production and availability in a stocking rate and grazing management experiment with dairy cows. Journal Agricultural Science, v.67, n.2, p.211-216, 1966.

CARASSAI, I.J.; NABINGER, C.; CARVALHO, P.C.F. et al. Recria de cordeiras em pastagem nativa melhorada submetida à fertilização nitrogenada: 1. Dinâmica da pastagem. Revista Brasileira de Zootecnia, v.37, n.8, p.1338-1346, 2008.

CASTILHOS, Z.M.S.; JACQUES, A.V.A. Pastagem natural melhorada pela sobressemeadura de trevo branco e adubação. Pesquisa Agropecuária Gaúcha, v.6, n.1, p.19-25, 2000.

CORREA, F.L.; SILVA, L.F.A. Carga e ganho animal em campo nativo melhorado. Montevideo: Instituto Nacional de Investigación Agropecuária, 1998. p.91-93 (Série Técnica, 94).

COMISSÃO DE QUÍMICA E FERTILIDADE DO SOLO - CQFS. Manual de adubação e calagem para os Estados do Rio Grande do Sul e Santa Catarina. 10.ed. Porto Alegre: Sociedade Brasileira de Ciência do Solo/Comissão de Química e Fertilidade do Solo, 2004. 400p.

DI RIENZO J.A.; CASANOVES F.; BALZARINI, M.G. et al. InfoStat versión 2010. Córdoba, Argentina: Grupo InfoStat, FCA, Universidad Nacional de Córdoba, 2010. 336p.

EMBRAPA - EMPRESA BRASILEIRA DE PESQUISA AGROPECUÁRIA. Centro Nacional de Pesquisa do Solo CNPS. Sistema Brasileiro de Classificação de Solos. 2.ed. Rio de Janeiro: Embrapa Solos, 2006. 306p.

FAGUNDES, J.I.B.; LOBATO, J.F.P.; SCHENKEL, F.S. Efeito de duas cargas animais em campo nativo e de duas idades de desmama no desempenho de vacas de corte primíparas. Revista Brasileira de Zootecnia, v.32, n.6, p.1722-1731, 2003.

FERREIRA, E.T.; NABINGER, C.; FREITAS, A.K. et al. Melhoramento do campo nativo: tecnologias e o impacto no sistema de produção. In: CICLO DE PALESTRAS EM PRODUÇÃO E MANEJO DE BOVINOS, 13., 2008, Canoas. Anais... Canoas: ULBRA, 2008. p.27-87.

FERREIRA, E.T.; NABINGER, C.; ELEJALDE, D.A.G. et al. Fertilization and oversowing on natural grassland: effects on pasture characteristics and yearling steers performance. Revista Brasileira de Zootecnia, v.40, n.9, p.2039-2047, 2011.

FONTANELI, R.S.; JACQUES, A.V.A.; HENRICH, C. et al. Efeito da ceifa, da queima, do diferimento e da adubação sobre uma pastagem natural. Revista Brasileira de Zootecnia, v.23, n.5, p.719-729, 1995.

FONTOURA JÚNIOR, J.A.S.; QUADROS, F.L.F.; MOOJEN, E.L. et al. Desempenho animal em pastagem natural com diferentes alternativas de introdução de espécies de estação fria. In: REUNIÃO DO GRUPO TÉCNICO EM FORRAGEIRAS DO
CONE SUL - ZONA CAMPOS, 18., 2000, Guarapuava. Anais... Guarapuava, 2000. p.149-150.

FREITAS, T.M.S. Dinâmica da produção de forragem, comportamento ingestivo e produção de ovelhas Ile de France em pastagem de azevém anual (Lolium multiflorum Lam) em resposta a doses de nitrogênio. 2003. 143f. Dissertação (Mestrado em Zootecnia) - Universidade Federal do Rio Grande do Sul, Porto Alegre.

GONÇALVES, E.N.; CARVALHO, P.C.F.; KUNRATH, T.R. et al. Relações planta-animal em ambiente pastoril heterogêneo: processo de ingestão de forragem. Revista Brasileira de Zootecnia, v.38, p.1655-1662, 2009

HART, R.H.; HOVELAND, C.S. Objectives of grazing trials. In: MARTEN, G.C. (Ed.). Grazing research: design, methodology and analysis. Wisconsin: CSSA, 1989. p.1-6.

KLINGMAN, D.L.; MILES, S.R.; MOTT, G.O. The cage method for determining consumption and yield of pasture herbage. Journal of Society Agronomy, v.35, n.9, p.739-746, 1943.

LEMAIRE, E.; CHAPMAN, D. Tissue flows in grazed plant comunities. In: HODGSON, I., ILLIUS, A.W. (Eds.). The ecology and management of grazing systems. Wallingford: CAB International, 1996. p.3-36.

LORENZI, H. Plantas daninhas do Brasil - terrestres, aquáticas, parasitas e tóxicas. 4.ed. Nova Odessa: Instituto Plantarum, 2008. p.672.

MARASCHIN, G.E.; MOOJEN, E.L.; ESCOSTEGUY, C.M.D. et al. Native pasture, forage on offer and animal response. In: INTERNATIONAL GRASSLAND CONGRESS, 18., 1997, Winnipeg. Proceedings... Winnipeg: Saskatoon, Canadá Paper 288. V.II. 1997. p.27-28.

MORENO, J.A. Clima do Rio Grande do Sul. Porto Alegre: Secretaria da Agricultura, 1961. 41p.

NABINGER, C.; FERREIRA, E.T.; FREITAS, A.K. et al. Produção animal com base no campo nativo: aplicações de resultados de pesquisa. In: PILLAR, V.P.; MÜLLER, S.C.; CASTILHOS, Z.M.S. et al. (Orgs.). Campos sulinos: conservação e uso sustentável da biodiversidade. Brasília: Ministério do Meio Ambiente, 2009. p.175-198.

RIZO, L.M.; MOOJEN, E.L.; QUADROS, F.L.F. et al. Desempenho de pastagem nativa e pastagem sobre-semeada com forrageiras hibernais com e sem glifosato. Ciência Rural, v.34, n.6, p.1921-1926, 2004.

SILVA, J.L.S.; JACQUES, A.V.A. Disponibilidade de forragem de uma pastagem natural sobressemeada com leguminosas perenes de estação quente. Revista Brasileira de Zootecnia, v.22, n.6, p.920-929, 1993.

STUEDMANN, J.A.; MATCHES, A.G. Measurements of animal response in grazing research. In: MARTEN, G.C. (Ed.). Grazing research: design, methodology and analysis. Wisconsin: CSSA, 1989. p.21-35.

TAIZ, L.; ZEIGER, E. Plant physiology. 4.ed. Sunderland: Sinauer Associates, 2006. p.467-508

TOTHIL, J.C. Regional course on meansurement of grassland vegetation. Santiago: FAO, 1979. 76p.

WERY, J. Relations entre la nutrition azotée et la production chez les légumineuses. In: GUY, P. (Ed.) Nutrition azotée des legumineuses. Paris: INRA, 1987. p.199-223. (Les Colloques de l'INRA, 37).

WILM, H.G.; COSTELLO, D.F.; KLIPPLE, G.E. Estimating forage yield by the double sampling method. Journal of American Society of Agronomy, v.36, n.1, p.194-203, 1944. 